Jurnal Ilmu Ilmu Agribisnis: Journal of Agribusiness Science, 9(3), Agustus 2021

\title{
SIKAP DAN PERMINTAAN KONSUMEN DALAM MENGONSUMSI KOPI (KASUS PADA NELAYAN DI KECAMATAN TELUK BETUNG TIMUR KOTA BANDAR LAMPUNG)
}

\author{
(Attitude and Demand in Consuming Coffee: Case of Fishermen in East Teluk Betung Sub District \\ Bandar Lampung City)
}

Renni Dwi Rahmawati, Teguh Endaryanto, Eka Kasymir

Jurusan Agribisnis, Fakultas Pertanian, Universitas Lampung, JL. Prof. Dr. Soemantri Brojonegoro No.1 Bandar Lampung 35145. E-mail: teguh.endaryanto@fp.unila.ac.id

\begin{abstract}
ABSTRAK
Coffee contains caffeine, which is often consumed by fishermen as their choice when working at night. This research aims to study fishermen's attitude toward consuming coffee and the factors that influence fishermen's demand for coffee in Teluk Betung Timur Sub-district. This research used a survey method with direct interviews using a questionnaire. Research was conducted in Teluk Betung Timur Sub-district in June-July 2020, using purposive sampling. Respondents were 54 fishermen with the criteria of fishermen who consume coffee at least four times in a month. Research data were analyzed descriptive quantitatively using a model of multiattribute Fishbein and multiple linear regression. Based on research results, Fishermen in Teluk Betung Timur Sub District Bandar Lampung City have a pretty good attitude category on consuming coffee with the most preferred attribute after-drink effect. The factors that influence fishermen's demand for coffee are the price of energy drinks, sugar prices, and types of coffee.
\end{abstract}

Key words: attitude in consuming, coffee, demand.

\section{PENDAHULUAN}

Budaya minum kopi sudah tumbuh dan berkembang di Indonesia sejak dahulu. Konsumen kopi yang identik dengan pria lanjut usia, saat ini sudah mulai dinikmati oleh semua kalangan. Menurut Wahyudian, Sumarwan, dan Hartoyo (2004), konsumsi kopi pada konsumen yang berusia 18 hingga 25 tahun lebih besar dibandingkan konsumen yang berusia 45 tahun.

Minuman kopi mengandung berbagai zat psikotropika, salah satunya adalah kafein. Kafein berperan dalam menstimulus produksi hormon kortison dan adrenalin yang dapat memberikan efek penghilang rasa kantuk, meningkatkan kesadaran pikiran, mental, dan fokus (Solikatun, Kartono dan Demartoto 2015). Hal tersebut menjadikan minuman kopi sering kali dijadikan sebagai pilihan saat bekerja pada malam hari.

Kota Bandar Lampung menjadi wilayah kota yang miliki area pesisir yang menjadi bagian dari Teluk Lampung. Kehidupan nelayan di Kota Bandar Lampung tersebar pada empat kecamatan yaitu Kecamatan Teluk Betung Timur, Kecamatan Teluk Betung Selatan, Kecamatan Panjang, dan
Kecamatan Bumi Waras. Kecamatan Teluk Betung Timur menjadi wilayah di Kota Bandar Lampung dengan populasi nelayan paling banyak dibandingkan dengan kecamatan lainnya.

Pekerjaan nelayan merupakan jenis pekerjaan berat, oleh karena itu diperlukan tenaga fisik yang sangat kuat. Sebagian besar nelayan membiasakan membawa bekal kopi setiap hari pada saat berangkat bekerja, alasan mereka membawa kopi untuk menghindari rasa kantuk saat bekerja pada malam hari, sehingga frekuensi meminum kopi yang dilakukan oleh nelayan dapat dikatakan tinggi (Ratnasari, Maryanto dan Paundrianagari 2015).

Kegiatan menangkap ikan yang dilakukan oleh nelayan di Kecamatan Teluk Betung Timur Kota Bandar Lampung dapat menggambarkan banyaknya konsumsi kopi yang dilakukan oleh nelayan. Sebelum mengonsumsi kopi seorang nelayan sudah memiliki sikap dengan pertimbangan-pertimbangan tertentu terhadap minuman kopi. Pemahaman atas sikap nelayan terhadap kopi dapat membantu para produsen kopi yang berkaitan dalam pengembangan produk dengan menyesuaikan kebutuhan dan selera konsumen. 
Sikap yang dimiliki oleh nelayan dalam mengonsumsi kopi tersebut menentukan permintaan nelayan terhadap kopi. Permintaan nelayan terhadap kopi dapat dipengaruhi oleh harga barang tersebut, harga barang lain, tingkat pendapatan, jumlah penduduk, dan selera. Besarnya permintaan tersebut yang akan mempengaruhi keinginan konsumen dalam membeli suatu produk. Berdasarkan latar belakang tersebut, perlu dilakukan penelitian terkait terkait sikap dan permintaan nelayan dalam mengonsumsi kopi. Penelitian ini dilakukan dengan tujuan untuk mengetahui sikap nelayan dalam mengonsumsi kopi dan faktor-faktor yang mempengaruhi permintaan nelayan terhadap kopi di Kecamatan Teluk Betung Timur Kota Bandar Lampung.

\section{METODE PENELITIAN}

Penelitian ini dilakukan dengan metode survei dengan lokasi penelitian di Kecamatan Teluk Betung Timur Kota Bandar Lampung. Lokasi penelitian ditentukan secara sengaja (purposive) dengan pertimbangan Kecamatan Teluk Betung Timur sebagai daerah dengan populasi nelayan paling banyak dibandingkan dengan daerah lainnya.

Teknik pengambilan sampel menggunakan purposive sampling dengan mendatangi nelayan yang memiliki kriteria minimal berusia 18 tahun dan mengonsumsi kopi minimal 4 kali dalam sebulan. Jumlah sampel dalam penelitian ini ditentukan menggunakan rumus Sugiyono (2013) sebanyak 54 nelayan yang diperoleh dari hasil perhitungan dari total populasi nelayan di Kecamatan Teluk Betung Timur.

Pengumpulan data dilakukan pada bulan Juni hingga Juli 2020. Data yang digunakan dalam penelitian ini adalah data primer dan sekunder.
Data primer diperoleh dari hasil wawancara dengan responden seperti identitas responden, jenis kopi, jumlah konsumsi, frekuensi konsumsi dalam satu hari, alasan mengonsumsi, tingkat kepentingan dan kepercayaan atribut kopi, serta variabel terikat dan bebas yang memengaruhi permintaan. Data sekunder diperoleh dari sumber literatur, instansi dan lembaga terkait seperti Kementrian Pertanian, Badan Pusat Statistik, dan Dinas Penanaman Modal dan Pelayanan Terpadu Satu Pintu Direktorat Jenderal

Sikap nelayan dalam mengonsumsi kopi dianalisis dengan menggunakan model Multiatribut Fishbein untuk menyatakan sikap nelayan terhadap atribut yang dimiliki oleh kopi. Secara matematis, rumus tersebut dapat diekspresikan sebagai berikut:

$$
\mathrm{A}_{0}=\sum_{\mathrm{i}=1}^{\mathrm{n}} \mathrm{b}_{\mathrm{i}} \mathrm{e}_{1}
$$

Keterangan :

$\mathrm{A}_{0}=$ Sikap terhadap suatu objek

$b_{i}=$ Kekuatan kepercayaan terhadap atribut $\mathrm{i}$

$\mathrm{e}_{\mathrm{i}}=$ Evaluasi terhadap atribut $\mathrm{i}$

$\mathrm{n}=$ Jumlah atribut yang dimiliki objek

Komponen bi mengukur kepercayaan nelayan terhadap atribut yang dimiliki kopi, sedangkan ei mengukur evaluasi kepentingan atribut yang dimiliki kopi. Atribut pada penelitian ini terdiri dari harga, rasa, aroma, merek, kekentalan, efek setelah minum, dan ketersediaan produk. Pengukuran atribut yang dilakukan pada model ini menggunakan skala Likert dengan rentang skala dari 1 sampai 5. Oleh karena itu, perlu dilakukannya uji validitas dan reliabilitas terhadap kuesioner penelitian yang digunakan. Hasil uji validitas dan reliabilitas tingkat kepentingan kepercayaan atribut kopi disajikan pada Tabel 1.

Tabel 1. Hasil uji validitas dan reliabilitas untuk tingkat kepentingan atribut kopi dan tingkat kepercayaan atribut kopi

\begin{tabular}{llcccc}
\hline & & \multicolumn{2}{c}{ Tingkat kepentingan } & \multicolumn{2}{c}{ Tingkat kepercayaan } \\
\cline { 3 - 6 } No. & Variabel indikator & $\begin{array}{c}\text { Corrected } \\
\text { Item-Total } \\
\text { Correlation }\end{array}$ & $\begin{array}{c}\text { Cronbach's } \\
\text { Alpha }\end{array}$ & $\begin{array}{c}\text { Corrected } \\
\text { Item-Total } \\
\text { Correlation }\end{array}$ & $\begin{array}{c}\text { Cronbach's } \\
\text { Alpha }\end{array}$ \\
\hline 1 & Harga & 0,61 & 0,79 & 0,46 & 0,71 \\
2 & Rasa & 0,72 & & 0,25 & \\
3 & Aroma & 0,51 & & 0,58 & \\
4 & Merek & 0,25 & & 0,60 & \\
5 & Kekentalan & 0,54 & & 0,37 & \\
6 & Efek setelah minum & 0,54 & & 0,52 & \\
7 & Ketersediaan produk & 0,50 & & 0,24 & \\
\hline
\end{tabular}


Uji validitas dan reliabilitas dalam penelitian ini bertujuan untuk menguji setiap pertanyaan dalam kuesioner tersebut apakah sudah sah dan handal untuk digunakan. Uji validitas dan reliabilitas dilakukan pada 30 responden dalam penelitian. Sufren dan Natanel (2013) menyatakan bahwa dalam uji validitas suatu kuesioner dikatakan baik apabila besarnya nilai corrected item dari total correlation diatas 0,20 . Pengujian reliabilitas pada Kuesioner yang dikatakan reliabel dan dapat diterima apabila besarnya nlai Cronbach alpha diatas 0,70 (Ghozali 2011). Berdasarkan Tabel 1, dapat diketahui bahwa kuesioner dalam penelitian ini sudah sah dan handal untuk digunakan.

Faktor-faktor yang memengaruhi permintaan nelayan terhadap kopi dianalisis dengan menggunakan metode analisis regresi linier berganda. Analisis regresi linier berganda adalah metode analisis yang menjelaskan hubungan antara variabel terikat atau dependent (Y) dengan dua atau lebih variabel bebas atau independent $\left(\mathrm{X}_{1}, \mathrm{X}_{2}, \ldots \mathrm{X}_{\mathrm{n}}\right)$. Variabel bebas dalam penelitian ini adalah harga kopi, harga teh, harga minuman berenergi, harga susu, harga gula, harga rokok, pendapatan nelayan, jumlah anggota keluarga, jenis kopi, dan selera. Jenis kopi dan selera dimasukkan sebagai variabel dummy. Jenis kopi yang dilihat dari jenis kopi yang dikonsumsi oleh nelayan dan selera dilihat dari tingkatan selera suka dan tidak suka. Variabel selera ini ditentukan dari skor evaluasi sikap konsumen, kemudian pengukurannya dilakukan dengan cara mengklasifikasikan skor sikap. Klasifikasi tersebut diperoleh dari hasil asumsi perkalian skor sikap paling tinggi untuk setiap atribut dikurangi skor sikap paling rendah untuk setiap atribut per individu nelayan. Nelayan dengan selera tidak suka, apabila skor sikap yang dimiliki sebesar 49636 sedangkan nelayan yang memiliki selera suka dengan skor sikap suka 637-1.225. Persamaan regresi linier berganda dalam penelitian ini secara matematik adalah sebagai berikut:

$$
\begin{aligned}
& \mathrm{Ln} Y=\ln \alpha+\beta_{\mu 1} \ln \mathrm{X}_{1}+\beta_{\mu 2} \ln \mathrm{X}_{2}+\beta_{\mu 3} \ln \mathrm{X}_{3} \\
& +\beta_{\mu 4} \ln X_{4}+\beta_{\mu 5} \ln X_{5}+\beta_{\mu 6} \ln X_{6} \\
& +\beta_{\mu 7} \ln X_{7}+\beta_{\mu 8} \ln X_{8}+\beta_{\mu 9} \ln D_{1} \\
& +\beta_{\mu 10} \ln \mathrm{D}_{2} \mathrm{u}
\end{aligned}
$$

Keterangan:

$$
\begin{array}{ll}
\mathrm{Y} & =\text { Permintaan kopi } \\
\alpha & =\text { Intersept } \\
\beta_{\mu \mathrm{i}} & =\text { Koefisien regresi parameter yang ditaksir } \\
\mathrm{X}_{1} & =\text { Harga kopi }(\mathrm{Rp} / \mathrm{kg}) \\
\mathrm{X}_{2} & =\text { Harga teh }(\mathrm{Rp} / \mathrm{kg}) \\
\mathrm{X}_{3} & =\text { Harga minuman berenergi }(\mathrm{Rp} / \mathrm{kg})
\end{array}
$$

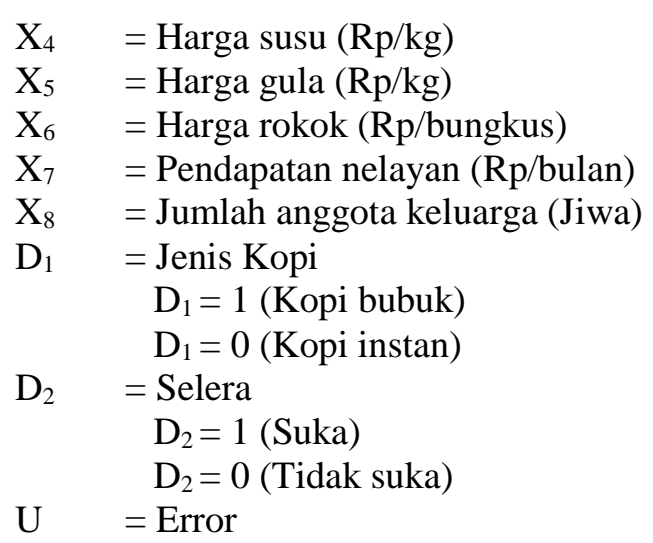

\section{HASIL DAN PEMBAHASAN}

\section{Karakteristik Responden}

Nelayan dalam penelitian ini secara keseluruhan berjenis kelamin laki-laki. Umur didominasi oleh nelayan dengan kategori umur yang relatif lebih tua yaitu rentang umur 37-42 tahun dengan pengalaman menjadi nelayan yang yang cukup lama yaitu 15-20 tahun. Berdasarkan tingkat pendidikan, terdapat responden tidak menempuh pendidikan hingga responden yang telah menempuh pendidikan SMA. Tingkat pendidikan terakhir responden yang paling banyak adalah SMP sebesar 38,89 persen. Pendapatan responden dalam penelitian ini adalah besarnya pendapatan rata-rata yang diterima oleh nelayan setiap bulan dari hasil tangkap ikan. Pendapatan nelayan berkisar Rp1.000.000-Rp3.000.000 dengan ratarata pendapatan sebesar Rp1.685.185 per bulan. Jumlah anggota keluarga ini mempengaruhi besarnya jumlah pengeluaran setiap harinya, sebagian besar keluarga nelayan memiliki anggota keluarga antara $3-5$ orang $(57,41 \%)$.

Pola konsumsi dalam penelitian ini berkaitan dengan jenis, merek, jumlah konsumsi, frekuensi konsumsi, dan pengeluaran dalam mengonsumsi. Hal tersebut sejalan dengan penelitian Hendaris, Zakaria, dan Kasymir (2013) yang melihat pola konsumsi dari jumlah, jenis, dan frekuensi yang mengonsumsi. Jenis kopi yang dikonsumsi oleh nelayan terdiri dari kopi bubuk dan kopi instan. Merek kopi bubuk yang dikonsumsi nelayan adalah kopi bubuk bola dunia, sedangkan kopi instan terdiri dari kapal api mix, ABC kopi susu, dan top kopi. Nelayan mengonsumsi kopi karena kebiasaan dan menghilangkan rasa kantuk saat bekerja pada malam hari. Pengumpulan data jumlah konsumsi kopi nelayan dilakukan dengan mengetahui besarnya rata-rata jumlah konsumsi kopi yang dilakukan pada saat melaut. Secara rinci dapat dilihat pada Tabel 2 . 
Tabel 2. Jumlah konsumsi kopi nelayan per bulan di Kecamatan Teluk Betung Timur Kota Bandar Lampung

\begin{tabular}{cccc}
\hline Jenis & \multicolumn{3}{c}{ Jumlah Konsumsi } \\
\hline \multirow{3}{*}{ Kopi } & $1,56-1,99$ & 17 & 35,42 \\
\cline { 2 - 4 } Bubuk & $2,00-2,43$ & 15 & 31,25 \\
& $2,44-2,88$ & 16 & 33,33 \\
\hline Jumlah & & 48 & 100,00 \\
\hline \multirow{2}{*}{ Kopi } & $\mathrm{kg} / 1$ bulan & $\mathrm{n}$ & $\%$ \\
\cline { 2 - 4 } Instan & 0,90 & 4 & 66,67 \\
& 1,05 & 2 & 33,33 \\
\hline Jumlah & & 6 & 100,00 \\
\hline
\end{tabular}

Rata-rata jumlah konsumsi kopi pada nelayan menunjukkan konsumsi kopi bubuk dan kopi instan per bulan per individu adalah $2,34 \mathrm{~kg}$ dan $0,95 \mathrm{~kg}$. Hasil tersebut menunjukan nelayan yang memilih kopi bubuk akan lebih banyak jumlah konsumsinya dibandingkan nelayan yang mengonsumsi kopi instan. Hal tersebut dikarenakan kopi instan yang dikonsumsi oleh nelayan sudah memiliki komposisi kopi dan gula yang ditentukan untuk setiap kemasan kopi instan, sedangkan nelayan yang mengonsumsi kopi bubuk dapat menentukan sendiri sesuai selera seberapa banyak kopi yang digunakan dalam satu gelas kopi. Selain itu, nelayan memiliki kebiasaan untuk menyeduh kopi bubuk dalam jumlah banyak, sehingga hal tersebut juga mempengaruhi banyaknya jumlah kopi dan gula yang ditentukan oleh nelayan. Besarnya jumlah konsumsi kopi nelayan dipengaruhi oleh banyak frekuensi konsumsi kopi yang dilakukan nelayan dalam satu hari pada saat melaut. Frekuensi konsumsi yang dilakukan dapat diketahui dari kebiasaan nelayan dalam mengonsumsi kopi pada saat melaut. Frekuensi konsumsi kopi bubuk dan instan nelayan dalam satu hari secara rinci dapat dilihat pada Tabel 3 .

Tabel 3. Frekuensi konsumsi kopi nelayan per hari di Kecamatan Teluk Betung Timur Kota Bandar Lampung

\begin{tabular}{cccc}
\hline Jenis & \multicolumn{3}{c}{ Frekuensi Konsumsi } \\
\hline \multirow{3}{*}{ Kopi Bubuk } & kali/hari & $\mathrm{n}$ & $\%$ \\
\cline { 2 - 4 } & $4-5$ & 19 & 39,58 \\
& $6-7$ & 26 & 60,42 \\
\hline Jumlah & & 48 & 100,00 \\
\hline \multirow{3}{*}{ Kopi Instan } & kali/hari & $\mathrm{n}$ & $\%$ \\
\cline { 2 - 4 } & 6 & 4 & 66,67 \\
& 7 & 2 & 33,33 \\
\hline Jumlah & & 6 & 100,00 \\
\hline
\end{tabular}

Rata-rata frekuensi konsumsi nelayan dalam mengonsumsi kopi bubuk dan kopi instan dalam sehari sebanyak enam kali per individu. Ditinjau dari frekuensi konsumsi antara kopi bubuk dan kopi instan menunjukan nelayan dalam mengonsumsi kopi instan lebih banyak yaitu pada rentang enam sampai tujuh kali dalam sehari sebesar 100 persen, sedangkan kopi bubuk pada rentang yang sama dikonsumsi oleh 60,42 persen. Hasil tersebut dikarenakan kopi instan lebih praktis untuk dikonsumsi dibandingkan dengan kopi bubuk.

Pengeluaran kopi adalah sejumlah biaya yang dikeluarkan nelayan untuk mengonsumsi kopi. Rata-rata pengeluaran nelayan dalam mengonsumsi kopi bubuk per bulan sebesar Rp183.299,22 dan rata-rata pengeluaran nelayan dalam mengonsumsi kopi instan per bulan sebesar Rp47.500,00.

\section{Sikap Konsumen}

Sikap seorang konsumen diduga memiliki korelasi yang positif dengan perilaku yang ditunjukan. Konsumen yang menyukai suatu produk atau bersikap positif akan cenderung memiliki keinginan untuk memilih dan membeli produk yang disukainya (Suryani 2012). Kopi menjadi sebuah kebutuhan bagi nelayan yang menyebabkan terjadinya konsumsi kopi secara berulang. Nelayan yang mengonsumsi akan memiliki penilaian terkait atribut kopi yang dianggap penting dan dipercayai. Penilaian tersebut diperoleh dari perhitungan sikap konsumen terhadap atribut kopi. Sikap konsumen terhadap kopi di Kecamatan Teluk Betung Timur diukur menggunakan model multiatribut Fishbein secara rinci dapat dilihat pada Tabel 4.

Tabel 4. Skor kepentingan (ei), kepercayaan (bi), dan sikap (Ao) nelayan terhadap atribut kopi di Kecamatan Teluk Betung Timur Kota Bandar Lampung.

\begin{tabular}{|c|c|c|c|c|}
\hline \multirow[t]{2}{*}{ No } & \multirow[t]{2}{*}{ Atribut Kopi } & $\begin{array}{c}\text { Skor } \\
\text { kepentingan }\end{array}$ & $\begin{array}{c}\text { Skor } \\
\text { kepercayaan }\end{array}$ & $\begin{array}{l}\text { Skor } \\
\text { sikap }\end{array}$ \\
\hline & & (ei) & (bi) & (eixbii) \\
\hline 1 & Harga & 4,04 & 3,70 & 14,95 \\
\hline 2 & Rasa & 4,11 & 3,85 & 15,82 \\
\hline 3 & Aroma & 3,96 & 3,91 & 15,48 \\
\hline 4 & Merek & 3,72 & 3,76 & 13,99 \\
\hline 5 & $\begin{array}{l}\text { Efek Setelah } \\
\text { Minum }\end{array}$ & 4,15 & 4,02 & 16,68 \\
\hline 6 & Kekentalan & 3,65 & 3,69 & 13,47 \\
\hline 7 & $\begin{array}{l}\text { Ketersediaan } \\
\text { Produk }\end{array}$ & 3,74 & 3,63 & 13,58 \\
\hline & & $\mathrm{o}=\sum \mathrm{BiEi}$ & & 103,97 \\
\hline
\end{tabular}


Hasil penilaian evaluasi kepentingan (ei) nelayan terhadap atribut kopi menunjukkan atribut efek setelah minum memiliki skor evaluasi tingkat kepentingan tertinggi sebesar 4,15. Nelayan menganggap bahwa kopi merupakan minuman penghilang rasa kantuk yang dapat dikonsumsi pada saat mereka bekerja pada malam hari. Atribut lain yang juga dianggap penting oleh nelayan adalah atribut rasa dengan skor evaluasi sebesar 4,11. Kopi menjadi pilihan para nelayan karena memiliki rasa yang khas dibandingkan dengan minuman lainnya. Hal ini sejalan dengan penelitian yang dilakukan oleh Epriani, Endaryanto dan Indriani (2017) yang menyatakan bahwa konsumen mengutamakan rasa dalam melakukan pembelian kopi bubuk. Selain itu, atribut harga juga dianggap penting oleh nelayan dengan skor evaluasi sebesar 4,04. Sejalan dengan penelitian yang dilakukan oleh Utama, Endaryanto, dan Kasymir (2017) yang menyatakan bahwa atribut rasa menjadi hal yang paling penting bagi konsumen dalam membentuk sikap terhadap minuman kopi dan atribut harga menjadi faktor penting yang dipertimbangan oleh sebagian besar konsumen, karena harga yang ditawarkan haruslah layak dan sesuai dengan apa yang diberikan oleh produsen kopi instan.

Hasil pengukuran tingkat kepercayaan (bi) nelayan terhadap kopi di Kecamatan Teluk Betung Timur dengan skor tertinggi adalah atribut efek setelah minum, kemudian diikuti oleh atribut aroma, rasa, merek, harga, kekentalan dan terendah adalah ketersediaan produk. Atribut efek setelah minum memiliki skor kepercayaan sebesar 4,02. Hal tersebut dikarekan kandungan kafein dalam kopiyang dapat menghilangkan rasa kantuk. Hal ini sesuai dengan penelitian yang dilakukan oleh Yulisa, Indriani dan Situmorang (2013) yang menyatakan bahwa variabel penghilang kantuk menjadi yang paling diharapkan konsumen pada saat mengonsumsi kopi bubuk instan siap saji.

Skor sikap diperolah dengan mengalikan skor kepentingan (ei) dengan skor kepercayaan (bi) yang dapat dilihat pada Tabel 3. Secara keseluruhan skor sikap konsumen (Ao) terhadap atribut kopi adalah sebesar 103,97. Atribut efek setelah minum memiliki skor sikap paling tinggi, kemudian diikuti oleh atribut rasa, aroma, harga, merek, ketersediaan produk, dan kekentalan. Efek setelah minum adalah akibat yang akan dirasakan nelayan saat atau setelah mengkonsumsi kopi. Hasil perhitungan skor sikap diketahui bahwa atribut efek setelah minum memiliki skor sikap sebesar 16,68. Nelayan mengonsumsi kopi dengan harapan dapat menghilangkan rasa kantuk saat bekerja pada malam hari. Hal tersebut sejalan dengan penelitian yang dilakukan oleh Dewi, Anwar dan Amalia (2009), yang menyatakan bahwa konsumen yang meminum kopi tidak cepat mengantuk setelah mengonsumsi kopi dibandingan kondisi biasa. Rasa adalah cita rasa kopi yang dirasakan oleh nelayan setelah mengonsumsi kopi. Atribut rasa dan aroma memiliki skor sikap yang tinggi setelah atribut efek setelah minum sebesar 15,82 dan 15,48 . Kopi yang memiliki rasa dan aroma khas akan memberikan kepuasan bagi konsumen dan berkeinginan untuk mengonsumsi produk kopi yang sama. Sejalan dengan penelitian yang dilakukan oleh Retnowati dan Abdurahman (2017) yang menyatakan bahwa atribut rasa memiliki skor sikap tertinggi dari seluruh atribut kopi. Rasa kopi yang kuat menjadi rasa seduhan kopi yang paling disukai konsumen. Sedangkan, atribut kekentalan menjadi atribut yang paling rendah dari sikap nelayan. Perhitungan skor sikap yang telah dilakukan dapat diketahui bahwa atribut kekentalan memiliki skor sikap sebesar 13,44. Hal tersebut dapat menjelaskan bahwa nelayan tidak mengukur kualitas kopi berdasarkan kekentalannya.

Perhitungan skor sikap nelayan dalam penelitian ini mengacu pada Nafisah (2013) yang menyatakan bahwa sikap dapat diinterpretasikan menjadi lima kategori sangat buruk, buruk, cukup baik, baik, dan sangat baik dari rata-rata skor sikap yang telah diketahui. Besarnya skala interval diperoleh dari total pengalian skor tertinggi tingkat kepentingan dan kepercayaan atribut kopi dikurangi dengam total pengalian skor terendah tingkat kepentingan dan kepercayaan atribut kopi, kemudian dibagi 5 sebagai jumlah ketegori yang diinginkan. Ratarata skor sikap nelayan terhadap atribut kopi di Kecamatan Teluk Betung Timur sebesar 14,85 berada pada interval 10,6 sampai dengan 15,3. Nilai tersebut dapat diketahui bahwa sikap nelayan terhadap atribut harga, rasa, aroma, merek, efek setelah minum, kekentalan, dan ketersediaan produk kopi dalam kategori cukup baik. Ketegori sikap dalam penelitian ini dapat dilihat pada Tabel 5.

Tabel 5. Kategori nilai sikap terhadap atribut kopi

\begin{tabular}{cr}
\hline Nilai Sikap Atribut & \multicolumn{1}{c}{ Nilai } \\
\hline Sangat Tidak Baik & $1,00 \leq$ Ao $\leq 5,70$ \\
Tidak Baik & $5,80 \leq$ Ao $\leq 10,50$ \\
Cukup Baik & $10,60 \leq$ Ao $\leq 15,30$ \\
Baik & $15,40 \leq$ Ao $\leq 20,10$ \\
Sangat Baik & $20,20 \leq$ Ao $\leq 25,00$ \\
\hline
\end{tabular}


Sikap pada penelitian ini di refleksikan pada selera. Selera diperoleh dari hasil perkalian atribut tingkat kepentingan dan kepercayaan nelayan untuk skor terendah dan tertinggi yang kemudian dibagi menjadi dua kategori. Kategori sikap tidak suka $(D=0)$ dengan skor 49-636 dan sikap suka $(D=1)$ dengan skor 637-1.225. Hasil tersebut diketahui bahwa nelayan dengan kategori selera menyukai kopi sebanyak 40 nelayan dan selera yang tidak menyukai kopi sebanyak 14 nelayan.

\section{Faktor-Faktor yang Memengaruhi Permintaan Nelayan Terhadap Kopi}

Keputusan pembelian menggambarkan jumlah konsumsi yang berkaitan dengan permintaan kopi yang dipengaruhi oleh beberapa faktor. Hasil regresi faktor-faktor yang mempengaruhi permintaan nelayan terhadap kopi di Kecamatan Teluk Betung Timur diperoleh nilai koefisien determinasi terkoreksi (R-Square) sebesar 0,83 yang artinya sebesar 83 persen variabel permintaan nelayan terhadap kopi dapat dijelaskan oleh variabel-variabel bebas yang telah dimasukan ke dalam model, sedangkan sisanya sebesar 17 persen dijelaskan oleh variabel lain yang tidak dimasukkan ke dalam model. Nilai F-hitung permintaan nelayan terhadap kopi sebesar 22,45 dengan tingkat kepercayaan 99 persen yang artinya secara bersama-sama variabel bebas berpengaruh sangat nyata terhadap permintaan kopi. Secara rinci hasil yang diperoleh disajikan pada Tabel 6 .

Tabel 6. Hasil regresi faktor-faktor yang mempengaruhi permintaan nelayan terhadap kopi di Kecamatan Teluk Betung Timur Kota Bandar Lampung

\begin{tabular}{lcc}
\hline \multirow{2}{*}{ Variabel } & \multicolumn{2}{c}{ Kopi } \\
\cline { 2 - 3 } C (konstanta) & Koefisien & Prob. \\
\hline Harga kopi (X1) & $-8,07$ & 0,22 \\
Harga teh(X2) & 0,35 & 0,28 \\
Harga minuman & $0,24 *$ & 0,13 \\
berenergi (X3) & 0,24 & 0,05 \\
Harga susu (X4) & $-0,51 * * *$ & 0,42 \\
Harga gula(X5) & 0,22 & 0,00 \\
Harga rokok (X6) & $-0,10$ & 0,33 \\
Pendapatan nelayan (X7) & $-0,01$ & 0,78 \\
Jumlah anggota keluarga (X8) & $0,63 * * *$ & 0,00 \\
Jenis kopi (D1) & $-0,05$ & 0,32 \\
Selera & 0,84 & \\
R-squared & 0,80 & \\
Adjusted R-squared & 22,46 \\
F hitung & 0,00 \\
*** = nyata pada tingkat kepercayaan 99 persen \\
* = nyata pada tingkat kepercayaan90 persen \\
\hline
\end{tabular}

Faktor-faktor yang berpengaruh nyata positif terhadap permintaan kopi adalah harga minuman berenergi dan jenis kopi, sedangkan harga gula berpengaruh nyata negatif. Apabila harga minuman berenergi mengalami kenaikan maka permintaan terhadap kopi akan meningkat, artinya minuman berenergi merupakan barang subtitusi kopi. Hal tersebut dapat terjadi karena kandungan kafein pada minuman berenergi. Hal ini sesuai dengan penelitian yang dilakukan Kusbaryanto (2003) menyatakan bahwa minuman berenergi memiliki beberapa kandungan yang salah satunya adalah kafein. Kafein akan menyebabkan konsumennya merasa tidak begitu mengantuk, tidak begitu lelah, daya pikir yang lebih cepat dan lebih jernih dibandingkan dengan yang tidak meminum kafein. Jenis kopi yang dipilih juga mempengaruhi besarnya permintaan kopi. Apabila konsumen mengonsumsi kopi bubuk permintaan kopi akan meningkat. Permintaan kopi oleh nelayan yang mengonsumsi kopi bubuk lebih besar dibandingkan dengan nelayan yang mengonsumsi kopi instan. Hal tersebut dapat terjadi karena konsumsi kopi bubuk yang dilakukan oleh nelayan cenderung lebih besar dibandingkan dengan konsumsi kopi instan.

Permintaan kopi akan menurun apabila harga gula mengalami kenaikan. Hal tersebut sejalan dengan penelitian yang dilakukan Nainggolan (2007) yang menyatakan bahwa harga gula berpengaruh negatif dan signifikan terhadap permintaan kopi di Sumatera Utara. Gula dan kopi merupakan barang pelengkap, sehingga apabila terjadi kenaikan harga pada salah satu barang tersebut akan menyebabkan penurunan harga barang lainnya.

Harga susu tidak mempengaruhi permintaan kopi yang artinya diartikan bahwa naik dan turunnya harga susu tidak mempengaruhi permintaan kopi. Sejalan dengan penelitian yang dilakukan oleh Putri, Prasmatiwi, Adawiyah (2015) yang menyatakan bahwa susu dan kopi merupakan barang pelengkap, namun memiliki hasil regresi yang tidak saling berpengaruh nyata antara keduanya jika terjadi perubahan harga pada salah satu barang tersebut, maka tidak akan menyebabkan terjadinya perubahan permintaan pada barang lainnya.

\section{KESIMPULAN}

Nelayan di Kecamatan Teluk Betung Timur Kota Bandar Lampung mempunyai sikap yang cukup baik dan baik dalam mengonsumsi kopi dengan atribut yang paling disukai adalah efek setelah 
minum. Faktor-faktor yang memengaruhi permintaan nelayan terhadap kopi di Kecamatan Teluk Betung Timur Kota Bandar Lampung adalah harga minuman berenergi, harga gula, dan jenis kopi.

\section{DAFTAR PUSTAKA}

Dewi FI., Anwar F., dan Amalia L. 2009. Persepsi terhadap konsumsi kopi dan teh mahasiswa tpb-ipb tahun ajaran 20072008. Jurnal Gizi dan Pangan. Vol 4. No. 1. Hal. 20 - 28. http://journal.ipb.ac.id/index.php/jgizipangan/article/view/4 516 [5 Agustus 2020].

Epriani M, Endaryanto T dan Indriani Y. 2017. Sikap konsumen dan strategi pemasaran dua merek kopi bubuk di Kota Bandar Lampung. Jurnal Ilmu Ilmu Agribisnis, 5 (4): 418. http://jurnal.fp.unila.ac.id/index.php/JIA/articl e/view/1751/1554 [20 Juli 2020].

Ghozali I. 2011. Aplikasi Analisis Multivariat dengan Program IBM SPSS 19. Badan Penerbit Universitas Diponegoro. Semarang.

Hendaris TW, Zakaria WA dan Kasymir E. 2013. Pola konsumsi dan atribut-atribut beras siger yang diinginkan konsumen rumah tangga di Kecamatan Natar Kabupaten Lampung Selatan. Jurnal Ilmu Ilmu Agribisnis, 1 (3): 233 https://jurnal.fp.unila.ac.id/index.php/JIA/article/view/578/540 [15 Desember 2020].

Kusbaryanto. 2003. Kandungan zat aktif pada beberapa jenis minuman berenergi. Jurnal Mutiara Medika. Vol. $3 . \quad$ No.1. https://journal.umy.ac.id/index.php/mm/article /view/1548/1594 [15 Agustus 2020].

Nafisah, S. A. 2013. Sikap dan persepsi konsumen terhadap jeruk lokal dan jeruk impor di pasar modern Kota Bogor. Skripsi. Institut Pertanian Bogor. Bogor.

Nainggolan H. 2007. Analisis Faktor-Faktor yang Mempengaruhi Permintaan Komoditi Kopi di Sumatera Utara. Tesis. Universitas Sumatra Utara. Medan. http://repository.usu.ac.id/bitstream/handle/123456789/7187/0 57018011.pdf?sequence $=1 \&$ isAllowed $=$ y $\quad[12$ Agustus 2020].

Putri EV, Prasmatiwi FE, dan Adawiyah R. 2015. Permintaan dan kepuasan konsumen rumah tangga dalam mengonsumsi susu bubuk di Bandar Lampung. Jurnal Ilmu Ilmu Agribisnis, 3 (4): 405-406. https://jurnal.fp.unila.ac.id/index.php/JIA/article/view/1090/9 95 [24 Juli 2020].
Ratnasari D, Maryanto S dan Paundrianagari MD. 2015. Hubungan kebiasaan konsumsi kopi dan aktivitas fisik dengan kejadian hipertensi pada laki-laki usia 35-50 tahun di wilayah kerja puskesmas teruwai Kecamatan Pujut Kabupaten Lombok Tengah. Jurnal Gizi dan Kesehatan, 7 (13). http://ejournalnwu.ac.id/article/view/1435739009 $[27$ November 2019].

Retnowati N dan Abdurahman A. 2017. Analisis sikap konsumen pada produk kopi (studi kasus pada Perusahaan Pdp Kahyangan Kabupaten Jember). Jurnal Ilmiah Inovasi, 17 (2). https://publikasi.polije.ac.id/index.php/jii/article/view/543 [13 November 2019].

Solikatun S, Kartono DT dan Demartoto A. 2015. Perilaku konsumsi kopi sebagai budaya masyarakat konsumsi. Jurnal Analisa Sosiologi, 6 (1): 60-74. https://jurnal.uns.ac.id/jas/article/view/17410 [22 Februari 2020]

Sudiyarto S, Widayanti S dan Kresna DM. 2012. Perilaku konsumen penikmat kopi tubruk dan kopi instan. Jurnal Sosial Ekonomi Pertanin, 6 (3). https://jurnal.unej.ac.id/index.php/JSEP/article/view/805 [15 Agustus 2020].

Sufren dan Natanael Y. 2013. Mahir Menggunakan SPSS Secara Otodidak. Kompas Gramedia. Jakarta.

Sugiyono. 2013. Metode Penelitian Pendidikan Pendekatan Kuantitatif, Kualitatif, dan $R \& D$. Alfabeta. Bandung.

Suryani T. 2012. Perilaku Konsumen : Implikasi pada Strategi Pemasaran. Graha Ilmu. Yogyakarta.

Utama DA, Endaryanto T dan Kasymir E. 2017. Analisis Sikap dan Kepuasan Konsumen Terhadap Kopi Instan Nescafe dan Torabika Pada Mahasiswa di Universitas Lampung. Skripsi. Fakultas Pertanian. Universitas Lampung. Bandar Lampung.

Wahyudian, Sumarwan U dan Hartoyo. 2004. Analisis faktor-faktor yang mempengaruhi konsumsi kopi dan analisis pemetaan beberapa merek kopi dan implikasinya pada pemasaran kopi. Jurnal Manajemen dan Agribisnis, 1 (1). http://journal.ipb.ac.id/index.php/jmagr/article/view/3357 [1 Oktober 2019]

Yulisa L, Indriani Y dan Situmorang S. 2013. Perilaku konsumsi mahasiswa Universitas Lampung terhadap kopi bubuk instan siap saji. Jurnal Ilmu - Ilmu Agribisnis. 1 (4): 331 http://jurnal.fp.unila.ac.id/index.php/JIA/article/view/708/650 [7 Agustus 2020]. 